\title{
Assessment of the Implications of Geotechnical Properties of Soils in Otukpa Area of Ogbadibo LGA, Benue State, Nigeria
}

\author{
Ameh Peter ${ }^{1, *}$, Igwe Ogbonnaya ${ }^{2}$, Abdullateef Lawal ${ }^{1,3}$, Mustapha Aliyu ${ }^{1}$, Isa Abdulmajid ${ }^{1}$, \\ Zakariyau K. Kazeem ${ }^{4}$ \\ ${ }^{1}$ Department of Applied Geology, Abubakar Tafawa Balewa University, Bauchi, Nigeria \\ ${ }^{2}$ University of Nigeria, Nsukka \\ ${ }^{3}$ University of Ibadan, Nigeria \\ ${ }^{4}$ Sitech Engineering Limited, Kaduna \\ *Corresponding author: ampitt87@yahoo.com
}

\begin{abstract}
This study evaluates the index and engineering properties of soils in Otukpa Area of Benue State towards ascertaining their suitability for use as fill and embankment, sub-base and base course material. Otukpa in Benue state Nigeria has vast reserve of sand and other aggregate materials that are presently been mined for various construction purposes. The area holds good potential for human population explosion in the near future. When massive infrastructural development commences, localized sourcing of materials would be necessary. Unfortunately, not much is known of the geotechnical properties of the sands in this area. Index and engineering test was conducted to achieve the aim. Gravel size particles are completely absent. Permeability of soil ranged from $7.8 \times 10^{-6}$ to $3.36 \times 10^{-4} \mathrm{~m} / \mathrm{sec}$ with moisture content of 11.38 to $14.16 \%$. Specific gravity was between 2.63 to $2.67 \mathrm{~g} / \mathrm{cm}^{3}$. UCS range from 31-45Kpa while LL and PL ranged between $27-35 \%$ and $10-18 \%$ respectively. MDD peak value was $1.85\left(\mathrm{~g} / \mathrm{cm}^{3}\right)$ at an OMC of $12.11 \%$ and lowest at $1.67\left(\mathrm{~g} / \mathrm{cm}^{3}\right)$ at an OMC of 11.99 . The geotechnical implication of the observed properties range from susceptibility to marginal volume change, differential settlement to low shearing resistance. These materials are quality reserves for fill, embankment and sub-base construction but not for bases.
\end{abstract}

Keywords: base, embankment, fill, otukpa, sands, sub-base

Cite This Article: Ameh Peter, Igwe Ogbonnaya, Abdullateef Lawal, Mustapha Aliyu, Isa Abdulmajid, and Zakariyau K. Kazeem, "Assessment of the Implications of Geotechnical Properties of Soils in Otukpa Area of Ogbadibo LGA, Benue State, Nigeria.” Journal of Geosciences and Geomatics, vol. 6, no. 1 (2018): 1-11. doi: 10.12691/jgg-6-1-1.

\section{Introduction}

Supply of building materials is key to construction business all over the world. The quality of construction material is also very important in the development of sustainable infrastructures. Different construction materials sourced from different location presents different engineering and geotechnical properties. These properties could be acquired from the parent materials, it could also be a reflection of the diagenetic history of the material, mode of formation, depositional environment as well as the prevailing source environment.

These properties determine the suitability of the material for construction purpose. Suffice to say that different materials are suited for different purposes. For Instance materials that have high permeability $(\mathrm{K})$ will be best suited for construction of highway sub-bases, drain structures and other similar-purpose infrastructures. Soils with very low permeability (K) would be the sought after when sourcing for materials with which to construct dams, embankments, landfills and other retaining structures. An idea of inherent soil properties that determine its suitability or otherwise for construction purpose can be deciphered by carrying out index and engineering tests on the soils.

Otukpa is a community in Benue state that is rich in aggregates that is presently been used for various construction purposes. The area holds a very good potential for human population explosion in the near future. This implies that more of the materials will be mined for construction purposes. Unfortunately, not much is known of the geotechnical properties of the soils in this area. It is thus necessary to study the soil to ascertain the geotechnical properties so as to understand their implications for various construction purposes that it may be used for. This is in an effort to expanding the resource-base of the construction-supply industry if they are found suitable and cautioning against further usage if they turn out as unsuitable to forestall future tragedies and economic losses. 


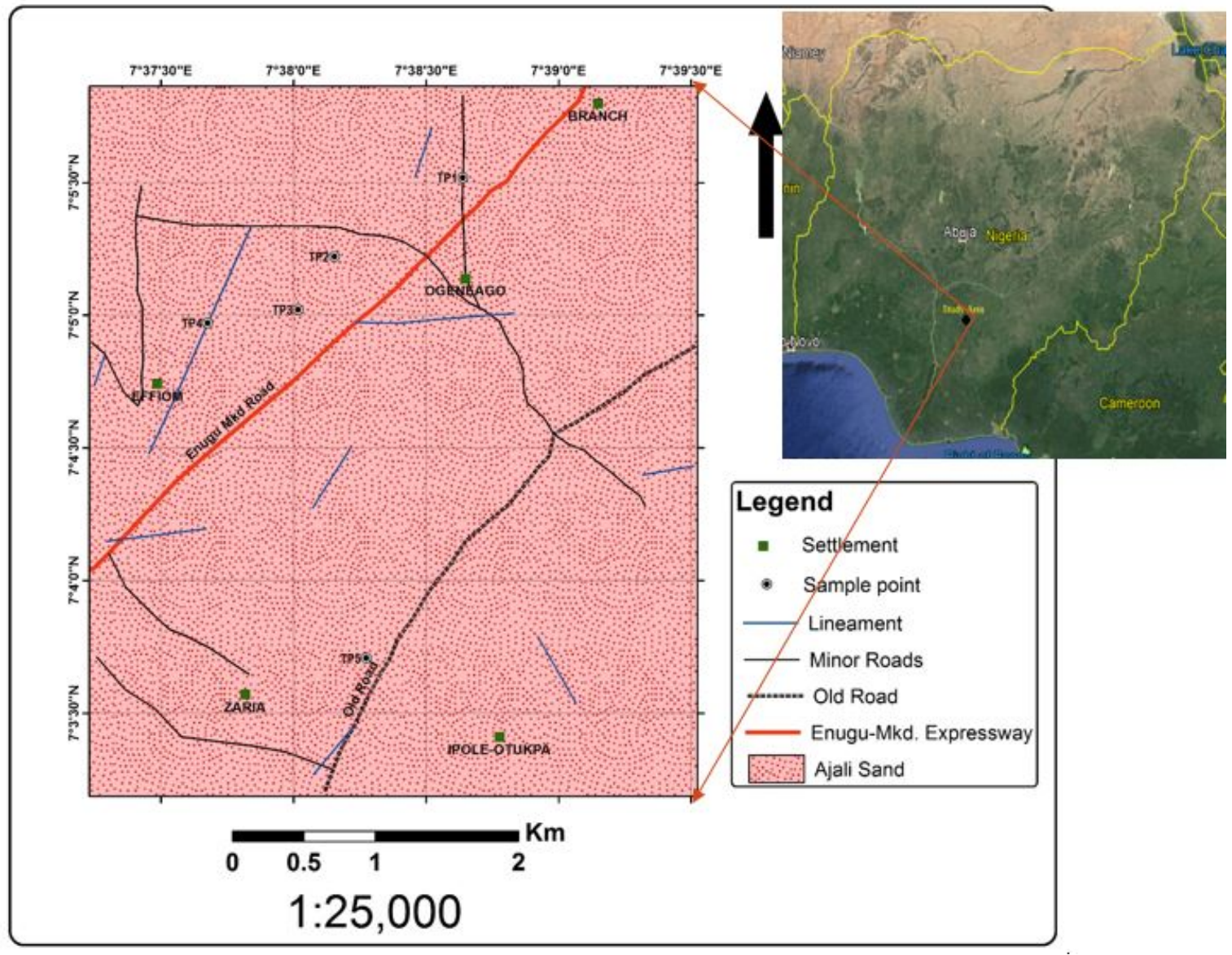

Figure 1. Geological map of the study area with inset of map of Nigeria showing the study area

This study is aimed at evaluating the index and engineering properties of soils in Otukpa Area of Benue State with a view to ascertaining their suitability for construction of engineering facilities such as fill and embankment, sub-base and base course. The over 300m thick Ajali sandstone which the area falls under covers a wide spatial area and presents a vast reserve of aggregate and laterite for the construction industry. It is currently been mined for use as aggregates for building of houses and as fill materials. It is thus useful to understand the geotechnical properties of the soil material (index and engineering) so as to make use of the materials in ways that they are best suited since the geotechnical properties of soils to a large extent determine its suitability for various purposes.

\section{Literature Review}

Reference [1] opined that in Nigeria, the paucity of information on the geotechnical properties of soils is the bane of most road failures noting that the integrity of the construction material used is as important as other design factors. Reference [2] reported that the performance of a highway pavement is influenced to a very considerable extent by the subgrade material. Different soils have different properties, it then underscores the need to carry out a detailed investigation on the properties of the soil as reference [3] posted that the geo-technical characteristics and engineering behavior of soils depend mainly on the genesis and degree of weathering Morphological characteristics as well as the type and content of secondary minerals are other genetic characteristic. Reference [1] noted that for proper design of a pavement, geotechnical parameters include the strength, the maximum dry density (MDD), the amount of fines (clay and silts) as well as the compaction performance of the proposed highway construction materials must be known. In the in-depth investigation of the geotechnical engineering properties of subgrade and base soils used in the construction of Omolayo Road in Akobo Area of Lagelu local government, Oyo State, Nigeria. Reference [1] collected subgrade samples at depths ranging from $0.5 \mathrm{~m}$ to $1.0 \mathrm{~m}$ while base sample were collected from a heap of laterite brought from the borrow-pit at Oluwo area along New Ife Express Road, Oyo State, Nigeria. The samples were subjected to several index test. The particle size analysis results showed that all samples, both subgrade and base were well graded since their Uniformity Coefficients were greater than 15. Base sample were seen to be more plastic compared to subgrade samples since it has highest percentage of clay passing sieve no. 200 (75 $\mu \mathrm{m})$. The liquid limit and plastic index were found to range from $24 \%$ to $48 \%$ and $2.7 \%$ to $25 \%$ respectively with base sample having the highest in both cases. This shows that base sample has high clay content and its load bearing capacity could be reduced when wet. The maximum dry densities ranged from $1.90 \mathrm{mg} / \mathrm{m} 3$ to $2.19 \mathrm{mg} / \mathrm{m} 3$ and Optimum moisture contents range from $5.4 \%$ to $14.2 \%$ respectively. The California bearing ratio is from $78 \%$ to 
$132 \%$ (unsoaked). The Specific gravity results ranged from 2.65 to 2.68. Based on these results, they concluded that the subgrade samples are excellent to good while base sample is fair to poor. Reference [4] noted that specifications for aggregates that are used in sub-base construction are based on knowledge that has been gained about the performance of similar aggregates when used for road construction and about the tests that best define the properties that are relevant to their performance. To assess the suitability of an aggregate for use in road construction, representative samples of the aggregate have to be subjected to these tests and the test results compared with values given in the specification. Reference [5] reported fine particles of 18-30\%, liquid limit of 53-64\%, plasticity index of $22-32 \%$, California bearing ratio of $47-69 \%$, uniaxial compressive strength of 1.22-1.28 MPa, and tensile strength of $0.80-0.84 \mathrm{MPa}$. A combination of 25-30 wt $\%$ of grain-fraction 5/20 granite aggregates (Los Angeles abrasion $<30 \%$ ) with $70-75 \mathrm{wt} \%$ of lateritic gravels provides concrete with California bearing ratio values of between 82 and 87 for lateritic gravels of eastern Cameroon. They concluded that the studied materials of Ngankè-Bonis area is suitable for use as base layers on roads ranging from Cameroon to the Central African. Reference [6] noted that the soils within the entire length of the Port Harcourt-Enugu expressway consist of concretionary laterite gravels, non-lateritic tropical sandy/clayey soils which are gravelly in some places and silty to fat clays formed from shales. Based on the particle size distribution and the plasticity of the majority of the soils. He concluded that by acceptance specifications, they are unsuitable for base materials. Field compaction results revealed that the relative compaction of 95-100\% can be easily achieved in the field using 10-12 ton vibratory rollers. Reference [7] assessed the suitability of Shale for use in construction projects. The results indicate that Abakaliki shale is likely to be satisfactory as a fill and embankment material, although the relatively high liquid limit and plasticity index may result in some swelling of the compacted shale. It is not suitable as a sub-base or base course for pavements. The Awgu and Enugu Shales may also serve well as fill and embankment materials, although their fines fraction is higher than the recommended limits. Both shales are unsuitable for use as sub-base or base course, unless improved. Heavy compaction was recommended wherever these materials are to be used for construction.
Based on the reviewed literatures, not much has been done on the geotechnical properties of soils in Otukpa area of Benue state Nigeria. It is thus timely and necessary to study the geotechnical properties of the soil moreso that the area is prone to development soonest. This work seeks to fill that vacuum by studying the index and engineering properties of the soils in the area.

\section{Geological Setting}

The area of study is bounded within N07 $03^{\prime} 12.5^{\prime \prime}$ to ${\mathrm{N} 07^{\circ}}^{\circ} 05^{\prime} 52.3^{\prime \prime}$ and longitude E07 $7^{\circ} 37^{\prime} 13.4^{\prime \prime}$ to E07 $39^{\prime} 31.25^{\prime \prime}$. The area is covered with friable fine to medium sized sand with pockets of laterites. The area is on 425 to $450 \mathrm{~m}$ elevation and is almost a flat plain with occasional gentle hills.

The Ajali sandstone overlies the Mamu Formation and has a diachronous age from South to North (Middle-upper Maastrichtian) and exhibits significant thickness variation from less than $300 \mathrm{~m}$ to over $1000 \mathrm{~m}$ at the center of the basin. Depositional characteristics are uniform for most parts of the basin, made up with textually mature sand facies. Dominant sedimentary structures are cross bedding.

The Anambra basin, which the area falls into is generally characterized by sediments of Cretaceous and younger ages. Detrital rocks are formed by the sedimentation of minerals and rock fragments that were derived from mechanical breakdown of pre-existing rocks in the source area, and were transported to a depositional site (basin).

The dominant topographic feature in the area is undulating topography or flat plains punctuated by inselbergs which stands as lone mounds of erosional resistors.

The area has a typical tropical climate which is marked predominantly by rainy season (April to October) and dry season (November to March) with an average annual temperature of $28^{\circ} \mathrm{c}$. The average relative humidity is highest in September and lowest in December or January with an average of $8 \%$. The average annual rainfall in the area is $1650 \mathrm{~mm}$ [8].

The area is seated on Ajali sandstone member of the Anambra basin. Evidence of diagenetic history, mode of formation, depositional environment as well as prevailing source environment are reflected on the grain textures, sedimentary structures, and mineralogical composition.
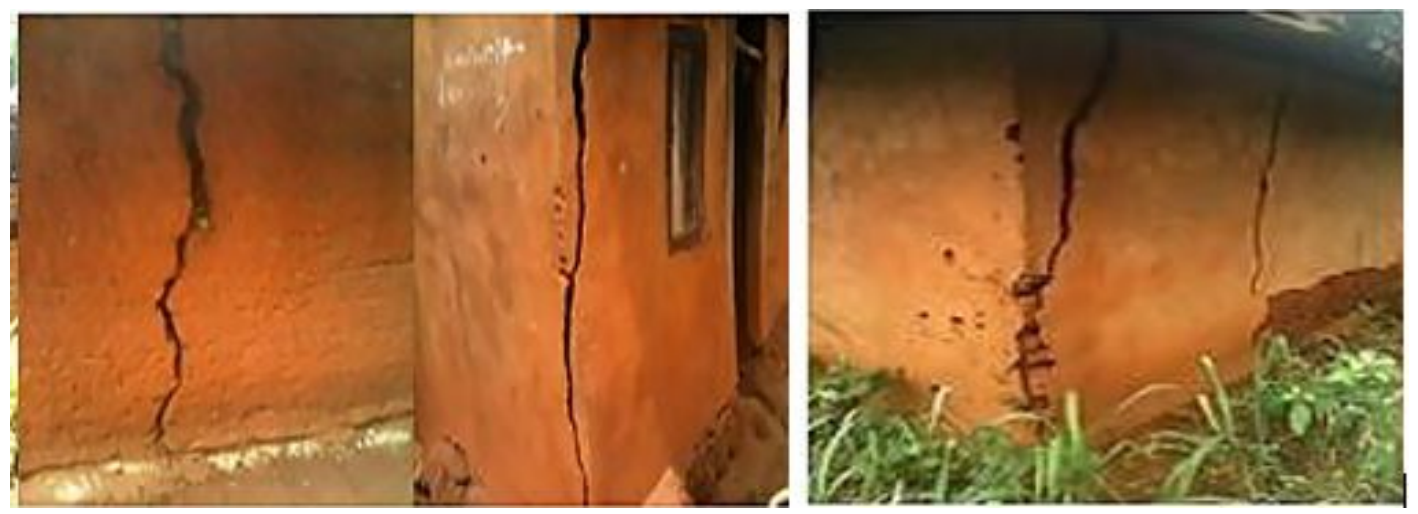

Figure 2. Pictures of failing buildings in the area 


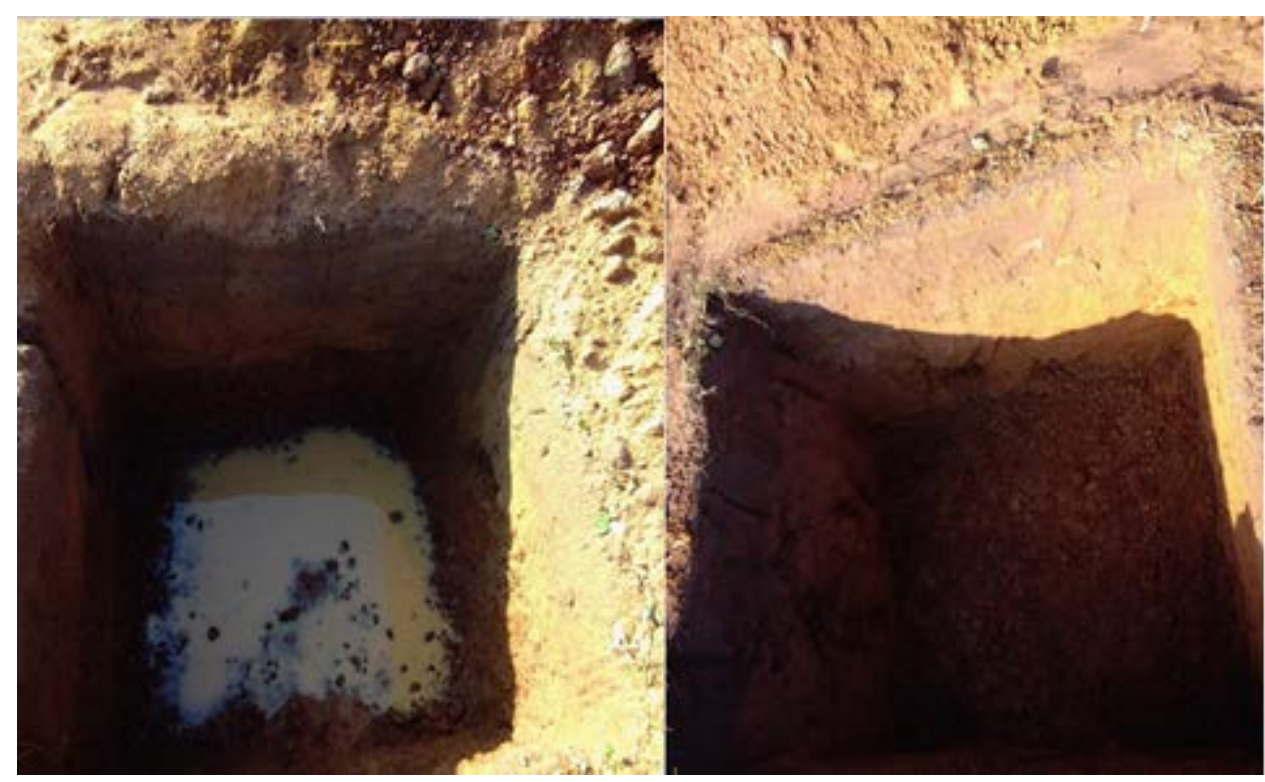

Figure 2b. Pictures of Test Pits (TP1 and TP5 respectively)

Lithology in the area is friable fine to medium grained, poorly- moderately sorted sandstones with major occurrence of mudrock breaks or sand-silt-clay heteroliths and pockets of laterites. Quartz is the dominant framework member and are well rounded. Rock fragments are rare. The major sedimentary structure in the area is the planar and tabular cross stratification [9]. Reference [10] presented that Ajali formation documents a spectrum of depositional environment ranging from continental through marginal marine to shallow marine. Palaeogeography and palaeocurrent trends established on the basis of grain size distribution pattern, field relation of the sandstones and palaeocurrent analysis in the study area showed that there were ancient rivers which were responsible for the transportation of clastic sediments from their parent pre-Santonian igneous and metamorphic rocks of the Nigerian Basement Complex and Oban Massif.

\section{Methodology}

The methodology adopted for this work is in two phases viz-

a) Preliminary investigation: This involved a geologic reconnaissance of the area to ascertain the lithology, spatial extent and spatial relationship as well as note geologic structures present. The information collected at this stage is delivered in the form of a geologic map of the area (Figure 1). This also afforded the opportunity to qualitative determine the size of the sand. An observation of how the sands are presently been used in the area was noted. A note of the performance of these material was also made. Some of the residential houses built with these materials are already showing signs of failure (Figure 2).

b) Geotechnical Sampling and Testing: Test pits of $1.5 \mathrm{~m}$ were dug at selected points as shown in Figure 1 and block samples of the sandy soil were collected from exposed earth surfaces. Sampling points and sampling density were determine considering the lithologic variability of the area, the stage or purpose of the investigation against the cost of investigation and the prevailing ground condition. Effort was made to ensure minimal disturbance during the sample collection and transportation to the laboratory. Index test such as specific gravity test, natural moisture content, Atterberg limit, grain-size distribution and unconfined compressive strength (UCS) were conducted on all the samples. Engineering test such as permeability, compaction, shear strength and consolidation test were also conducted on all the samples because although they are largely sands, it contained a proportionate amount of finer soils. These test were selected since according to [4] to assess the suitability of an aggregate for use in road construction, representative samples of the aggregate have to be subjected to tests and these test must be tests that best define the properties that are relevant to their performance and the test results compared with values given in the specification. All test for engineering parameters were conducted in accordance with B.S.1377 (BSI 1975) and all classification were done according to the Unified soil classification scheme (USCS).

The results of the test are compared with standard stipulated by the Nigerian federal ministry of works and housing [11] for fill, sub-base and base course materials respectively to determine their suitability or otherwise in Nigeria as well as explain their implication for geotechnical engineering.

\section{Result and Discussion}

Soils in TP1 and TP5 have similar characteristics. They appear moist and relatively cohesive with good proportion of fines mixed with the sands. Grains of sand recovered from this point are largely angular to sub-angular. It is brown colored. Samples from TP2 and TP3 also showed similar characteristics. They appear moist and soft, less cohesive with very low proportion of fines among the sand. Texturally, the sands are largely equigranular and rounded. It has a sharp gritty feel. It is also brown colored. TP4 feels gritty and moist. It is non-cohesive and appears poorly graded. It appeared whitish in color. The grains appear almost equigranular. 


\subsection{Natural Moisture Content}

The natural moisture content is presented in Table 1 . It range from 14.16 (TP5) to 11.38 (TP1). The natural moisture content of all the samples seems to be very high compared to that usually observed for same kind of clayey Sands. This may be due to the fact that the samples were collected at the peak of the wet season when samples have been inundated with water. This however gives an idea of the water retention ability of the soil. This is expected to affect the compressibility of the soil as well as the shear test because the moisture content of soils is an index parameter that determine the compressibility of the soil since according to Terzaghi reported in [12,13], it is only pore/void water expelled that result in change in volume (consolidation) of the soil.

Table 1. Table of specific Gravity, moisture content and Permeability

\begin{tabular}{|c|c|c|c|}
\hline \multirow{2}{*}{ Sample ID } & \multicolumn{3}{|c|}{ Test } \\
\cline { 2 - 4 } & $\begin{array}{c}\text { Specific Gravity } \\
\left(\mathrm{g} / \mathrm{cm}^{3}\right)\end{array}$ & $\begin{array}{c}\text { Moisture Content } \\
(\%)\end{array}$ & $\begin{array}{c}\text { Permeability K } \\
(\mathrm{m} / \mathrm{sec})\end{array}$ \\
\hline TP1 & 2.64 & 11.4 & $7.8 \times 10^{-6}$ \\
\hline TP2 & 2.63 & 13.9 & $1.4 \times 10^{-5}$ \\
\hline TP3 & 2.67 & 12.9 & $1.13 \times 10^{-5}$ \\
\hline TP4 & 2.57 & 13.6 & $3.36 \times 10^{-4}$ \\
\hline TP5 & 2.67 & 14.2 & $7.01 \times 10^{-6}$ \\
\hline
\end{tabular}

\subsection{Specific Gravity}

The specific gravity of soil samples range from 2.57 to 2.67 as shown in Table 1 . This is an index test whose value express the unit weight of a sample compared to the unit weight of equal volume of water under same temperature [12]. Specific gravity is an index test that gives an idea of how the soil particles are closely/densely packed together. Sample TP5 presents a noteworthy scenario because it has a high specific gravity of 2.67 and still reported the highest moisture content of 14.16. This result is unexpected considering the relationship that exist between specific gravity, moisture content and pore volume [12]. This situation can be explained by the fact that the activity of TP5 reported as normal. This means that the area has some clays (kaolinite) and the excess water content could be as a result of the adsorbed water associated with the clay minerals. The clay minerals may also resulted in very low permeability of the sample reported in Table 1.

\subsection{Grain Size Distribution}

The grain size distribution curves of samples across the area shows that the area has largely similar grain size distribution as shown by the stacked grain size distribution curves presented as Figure 3. Analysis of the curve shows that the area is sand heavy or sand dominated with no gravel sized particles and small amounts of fine sized particles. This size distribution is shown quantitatively in Table 2. Based on the grain size distribution, it is expected that the soil samples would show some fine-grained soil characteristics like cohesiveness, water retention and plasticity.

Table 2. Quantitative grain size distribution

\begin{tabular}{|c|c|c|c|c|c|}
\hline \multirow{2}{*}{ Grain size } & \multicolumn{5}{|c|}{ SAMPLE ID } \\
\cline { 2 - 6 } & TP1 & TP2 & TP3 & TP4 & TP5 \\
\hline Gravels (\%) & 0.0 & 0.0 & 0.0 & 0.0 & 0.0 \\
\hline Sands (\%) & 81.7 & 88.0 & 83.4 & 89.0 & 86.1 \\
\hline Fines (\%) & 18.3 & 12.0 & 16.6 & 11.0 & 13.9 \\
\hline
\end{tabular}

The dominance of sand in the area is shown by the high gradient of the sand portion of the distribution curve and almost linear fine portion of the curve. The samples are generally moderately well graded. Based on the grain size distribution in the area samples TP1, TP2, TP3, TP4 and TP5 classed as SC, SP-SM, SP-SM, SM and SC respectively as shown in Table 3 (USCS classification scheme).

Table 3. Table of Atterberg limits and consistency Index

\begin{tabular}{|c|c|c|c|c|c|}
\hline \multirow{2}{*}{ Test } & \multicolumn{5}{|c|}{ Sample Identity } \\
\cline { 2 - 6 } & TP1 & TP2 & TP3 & TP4 & TP5 \\
\hline LL (\%) & 28.0 & 28.0 & 27.0 & 28.0 & 35.0 \\
\hline PL (\%) & 17.0 & 16.0 & 10.0 & NP & 18.0 \\
\hline PI (\%) & 11.0 & 12.0 & 17.0 & NP & 17.0 \\
\hline LI (\%) & -51.1 & -17.3 & -16.8 & NP & -22.6 \\
\hline CI (\%) & 151.1 & 117.3 & 83.2 & NP & 122.6 \\
\hline USCS & SC & SP-SM & SP-SM & SM & SC \\
\hline
\end{tabular}

* NP=Non-plastic.

This is good for structures because the interlocking relationship between the fines and the aggregates would result in high shear strength of the area and low permeability. We expect a little pore pressure to build up as a result of the low permeability that will result. This pore pressure will not affect structures in the area because [14] showed that the water table in the area is at a depth of $201 \mathrm{~m}$.

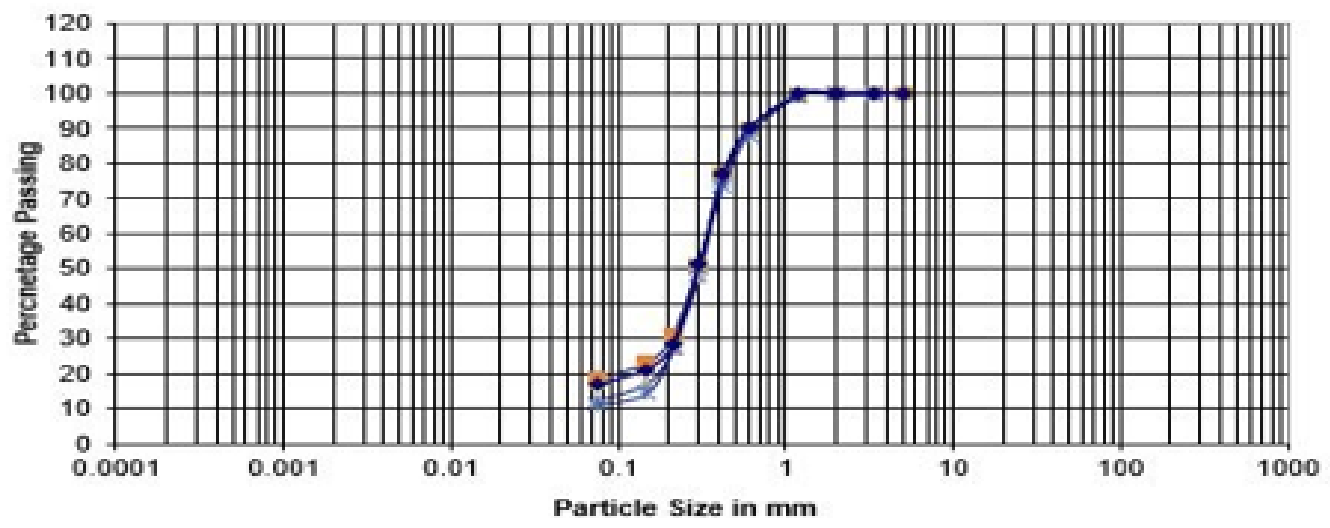

Figure 3. Stacked grain size distribution of all samples in the area 


\subsection{Atterberg's Limit}

The Atterberg limit parameters show largely similar characteristic for all samples as observed in grain-size distribution except for TP1. A summary of the Atterberg limit parameters for the area is presented as Table 3. The moisture content at which the soil starts to behave as a liquid material range from 27(TP3) to 35 (TP5) while the smallest water content at which the soil starts behaving like a plastic material range from 10 (TP3) to 18 (TP5). Consequently, the plastic limit range from 11 (TP1) to 17 (TP3 and IP1). Liquidity index range from -51.1 (TP1) to -16.8 (TP3) while the consistency index range from 151.1 (TP1) to 83.2 (TP3). The plastic and liquid limit result of samples across the area shows that samples from the area will change consistency state when there is change in moisture contents. The sample with the highest water content required for a change of state was reported by sample TP5 maybe because of the "normal" level of activity of the clay (Table 4) and the high moisture content and void spaces (Table 1). Plasticity index also show that samples across the area will behave plastically when subjected to varying water contents except sample TP4 that reported as non- plastic. The PI also suggest that the fine fraction of the soil contains some clay minerals hence the plastic behavior. Consistency and liquidity indices are used to show the stress history of the sample as well as provide information for interpreting several soil mechanical and physical properties such as shear strength, compressibility, shrinkage and swelling potentials [15]. It also tells the consistency state in which the sample was collected from the field. All samples reported negative values of liquidity index, this suggest that all the samples were collected at firm state with water content far less than the liquid limit. Also, all samples except TP3 reported above $100 \%$ consistency index. This also suggest that the samples were at a firm state with moisture contents lower than the plastic limit (on the dry side of the plastic limit range). Sample TP3 with consistency index at 83.2 suggest that the sample was collected at a firm state but the water content was within the plastic water content range. The activity of the clay in the area was calculated using the relation:

\section{Activity $=$ Plasticity Index (PI) / Amount of fines(clays).}

The result was compared with the Skempton (1953) activity chart [16] and presented as Table 5. This showed that the activity of samples in the area ranged from inactive through normal to active. The activity of clay in the area is seen to be the reason for anomalies in relationship between specific gravity, moisture content, permeability and consolidation in the area. The geotechnical implication of the Atterberg limit result is that soils in the area are susceptible to volume change (swelling and shrinkage) when there is a change in water content of the soil. The mere fact that Atterberg limit test could be performed on the sample shows that the soil is not completely granular. The result of the grain size distribution also suggest same. This means that the soil contain some fines (clays) which results in some cohesiveness in the soil samples. This observation calls for caution in the use of this material for construction purposes. Notably, the smallest volume change is expected around TP5.
Table 4. Activity of fines in the area (After Skempton, 1953)

\begin{tabular}{|c|c|c|}
\hline $\begin{array}{c}\text { Sample } \\
\text { ID }\end{array}$ & Activity & Interpretation \\
\hline TP1 & 0.60 & Inactive \\
\hline TP2 & 1.00 & Normal \\
\hline TP3 & 1.57 & Active \\
\hline TP4 & NP & Non-Plastic \\
\hline TP5 & 1.22 & Normal \\
\hline
\end{tabular}

\subsection{Compaction}

The compaction result obtained from a Proctor compaction test apparatus is presented as the stacked compaction curve in Figure 4. TP 5 shows the highest maximum dry density of $1.85 \mathrm{~g} / \mathrm{cm}^{3}$ at an optimum moisture content of 12.11 while maximum dry density of $1.67 \mathrm{~g} / \mathrm{cm} 3$ at an optimum moisture content of TP3 and TP4 is the lowest for the area. The Zero-air -void plots presented as Figure 6a-e shows that all of the samples are many points from attaining maximum compaction or $100 \%$ zero air void. Thus the void spaces will contain lots of air and will require good compactive effort to improve its engineering properties. The OMC and the natural moisture content shows that all except TP1 exist with natural moisture content greater than the OMC in its natural state (compacted at wet side naturally).The implication of the compaction test result is that continued addition of water leads to volume change and resultant fall in dry density if the soil is not compacted in place. This however will not be the case if the soil is compacted in place. The best soil for foundation is soil with high MDD at low OWC. Therefore, the soils need to be compacted to maximum dry density at other water content level with greater compactive effort at the dry side of the compaction curve. Therefore more compaction with greater compactive energy should be done to attain better compaction values and improved engineering properties.

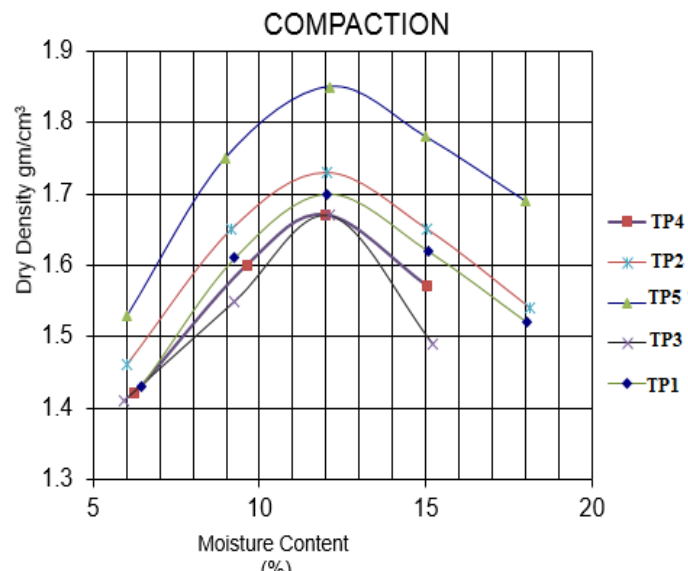

(\%)

Figure 4. Stacked compaction curve for all the samples

\subsection{Unconfined Compressive Strength}

The unconfined compressive test was conducted to determine the unconfined shear strength $\left(\mathrm{q}_{\mathrm{u}}\right)$ of the material. This is a test usually conducted to observe the behavior of the soil material under static axial/vertical load. The result of the UCS test is presented in Table 5. It 
is seen that the shear strength is highest at TP5 $\left(45 \mathrm{kN} / \mathrm{m}^{2}\right)$ and lowest at TP4 $\left(31 \mathrm{kN} / \mathrm{m}^{2}\right)$. This may be due to the fact that sample TP4 is non-plastic and does not have the strength component due to clays cohesiveness and water. The unconfined shear strength was taken as half the $\left(\mathrm{q}_{\mathrm{u}}\right)$ [17] as is seen to follow the same trend as the $\mathrm{q}_{\mathrm{u}}$. Observation of UCS failure curves shown as Figure 5 shows that all the sample deforms somewhat ductily as seen from the sinusoidal nature of the curve showing "deformation endurance" except the non-plastic TP4 whose deformation trend is slightly different. Also, the shear strengths of samples in the area was observed to be generally low. These is may be due to the fact that the area is dominantly sand.

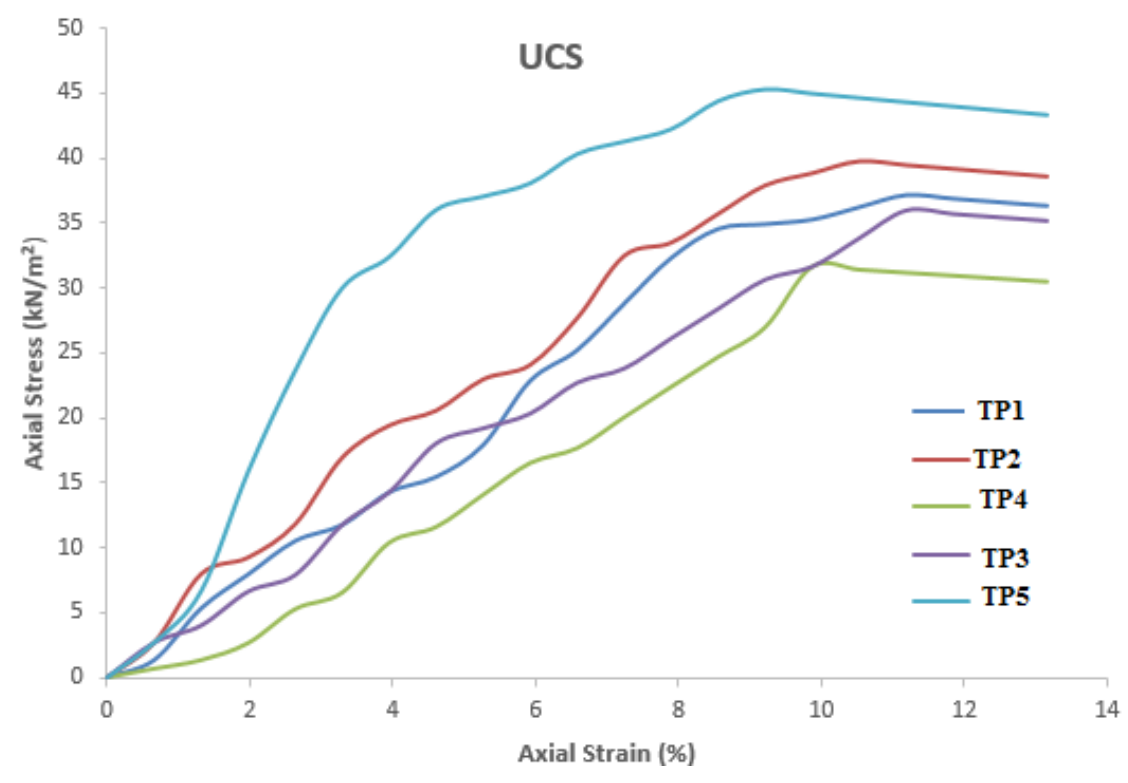

Figure 5. UCS failure curves for all samples

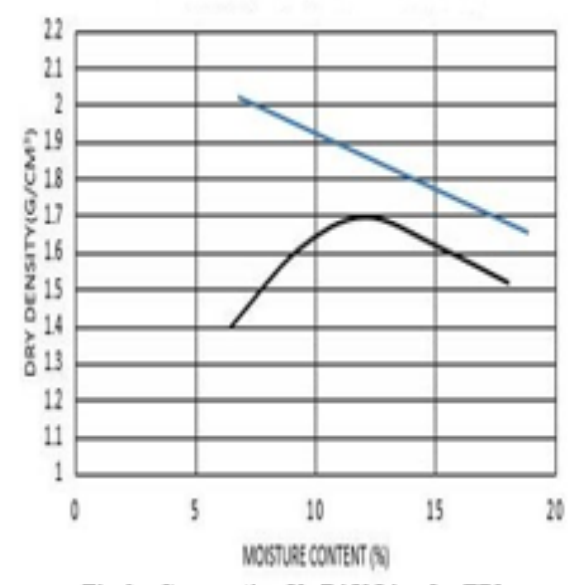

Fig 6a: Compaction Vs ZAV Line for TP1

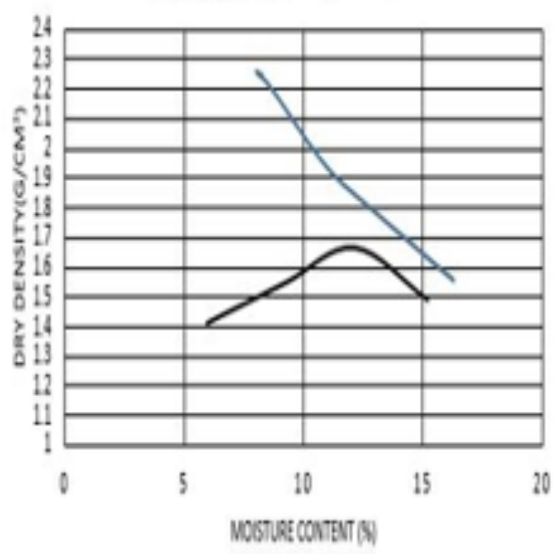

Fig 6d: Compaction Vs ZAV line for TP4

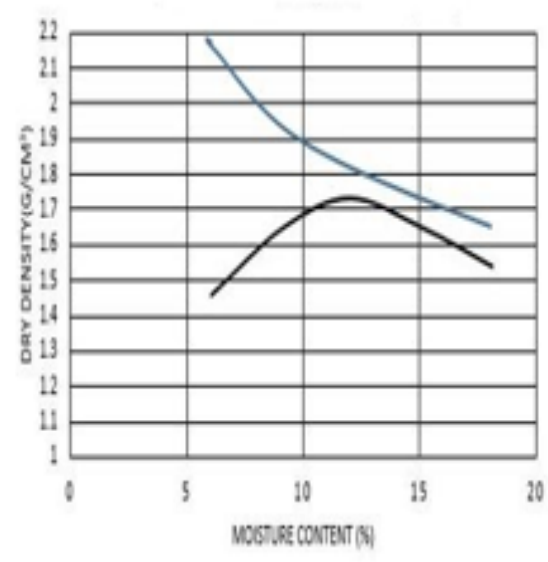

Fig 6b: Compaction V5 ZAV line for TP2

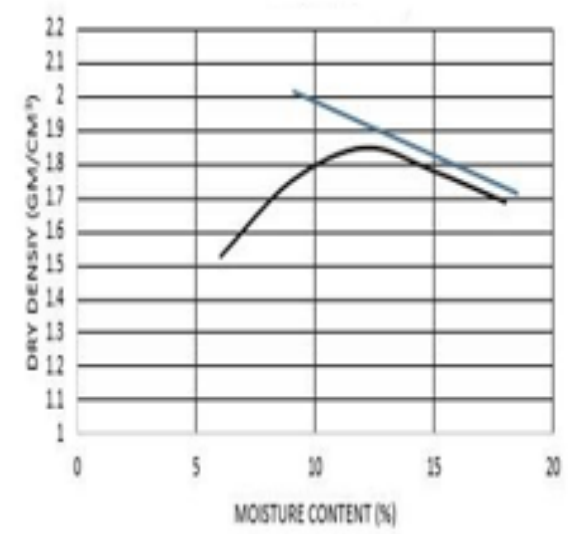

Fig 6e: Compaction Vs ZAV line for TP4

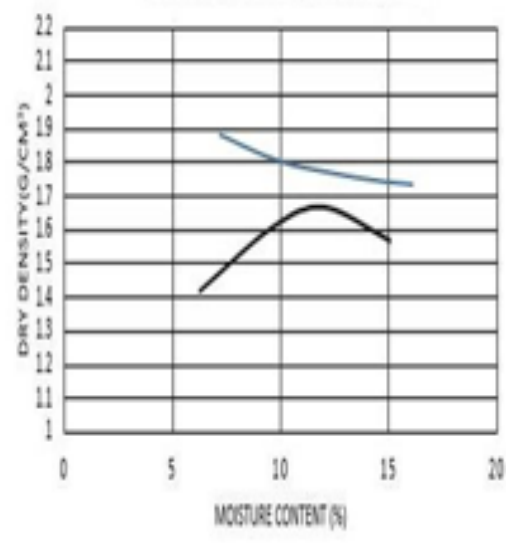

Fig 6c: compaction Vs ZAV line for TP3

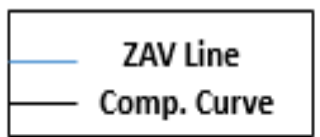


Table 5. Table of UCS Parameters

\begin{tabular}{|c|c|c|c|c|c|}
\hline \multirow{2}{*}{$\begin{array}{c}\text { UCS } \\
\text { PARAMETER }\end{array}$} & \multicolumn{5}{|c|}{ SAMPLE ID } \\
\cline { 2 - 6 } & TP1 & TP2 & TP3 & TP4 & TP5 \\
\hline $\mathrm{Q}_{\mathrm{U}}\left(\mathrm{kN} / \mathrm{m}^{2}\right)$ & 37 & 40 & 31 & 36 & 45 \\
\hline $\mathrm{C}\left(\mathrm{kN} / \mathrm{m}^{2}\right)$ & 19 & 20 & 16 & 18 & 23 \\
\hline
\end{tabular}

\subsection{Permeability (K)}

The hydraulic conductivity of the soils in the area measured from the falling head permeability test is presented in Table 1 . Fluid movement is easiest at the non-plastic TP4 $\left(3.36^{*} 10^{-3}\right)$ and most tortuous at TP1 $\left(7.8^{*} 10^{-6}\right)$. The permeability of soil in the area is seen to follow specific gravity, grain size distribution and activity of the clay. This observation readily presents the role of clays and fines in reducing permeability of soil materials. $[18,19,20]$.

\subsection{Consolidation}

The oedometer method of determining the 1D-consolidation of soil was done with one- directional drainage allowed [14]. The calculated consolidation values of $C_{v}$ and $M_{v}$ at a stress level of $250 \mathrm{kN}$ are presented as Table 6 . It should be noted that these calculated values are not fixed parameters even for a given sample of soil but are stress dependent. At $250 \mathrm{kN}$, Sample TP4 presents the highest rate of consolidation $\left(\mathrm{C}_{\mathrm{v}}\right)$ while TP3 present the lowest rate of consolidation $\left(\mathrm{C}_{\mathrm{v}}\right)$. This observation can be explained by the fact that sample TP4 is non-plastic and as such would contain pore spaces which will be squeezed and closed up resulting in the highest $\mathrm{C}_{\mathrm{v}}$ compared to others that have clays that clogged and reduced the pore volume. The coefficient of volume change $\left(\mathrm{M}_{\mathrm{v}}\right)$ peaks at TP1 $\left(3.17 \times 10^{-4}\right)$ and is lowest at TP2 $\left(7.27 \times 10^{-5}\right)$. Consolidation in the area is seen to follow the moisture content. This agreed with Terzaghi's theory of primary consolidation. A typical consolidation curve of a sample in the area is presented as Figure 7. The Sample which the figure represents appeared moist and soft, less cohesive with very low proportion of fines among the sand. Texturally, the sands are largely equigranular and rounded with a gritty feel. The stress level with which the consolidation was done rose gradually from $50 \mathrm{kN}$ to $250 \mathrm{kN}$. Since consolidation observed in the area is varied according to the amount of moisture content, differential settlement is expected.

Table 6. Consolidation parameters

\begin{tabular}{|c|c|c|}
\hline $\begin{array}{c}\text { Sample } \\
\text { ID }\end{array}$ & $\begin{array}{c}\mathrm{C}_{\mathrm{v}} \\
\left(\mathrm{M}^{2} / \mathrm{yrs} .\right)\end{array}$ & $\begin{array}{c}\mathrm{M}_{\mathrm{v}} \\
\left(\mathrm{M}^{2} / \mathrm{KN}\right)\end{array}$ \\
\hline TP1 & 3.96 & $3.17 \times 10^{-4}$ \\
\hline TP2 & 2.61 & $7.27 \times 10^{-5}$ \\
\hline TP3 & 1.33 & $2.05 \times 10^{-4}$ \\
\hline TP4 & 7.40 & $4.64 \times 10^{-5}$ \\
\hline TP5 & 2.43 & $1.39 \times 10^{-4}$ \\
\hline
\end{tabular}
$\sqrt{t}(\operatorname{man})$

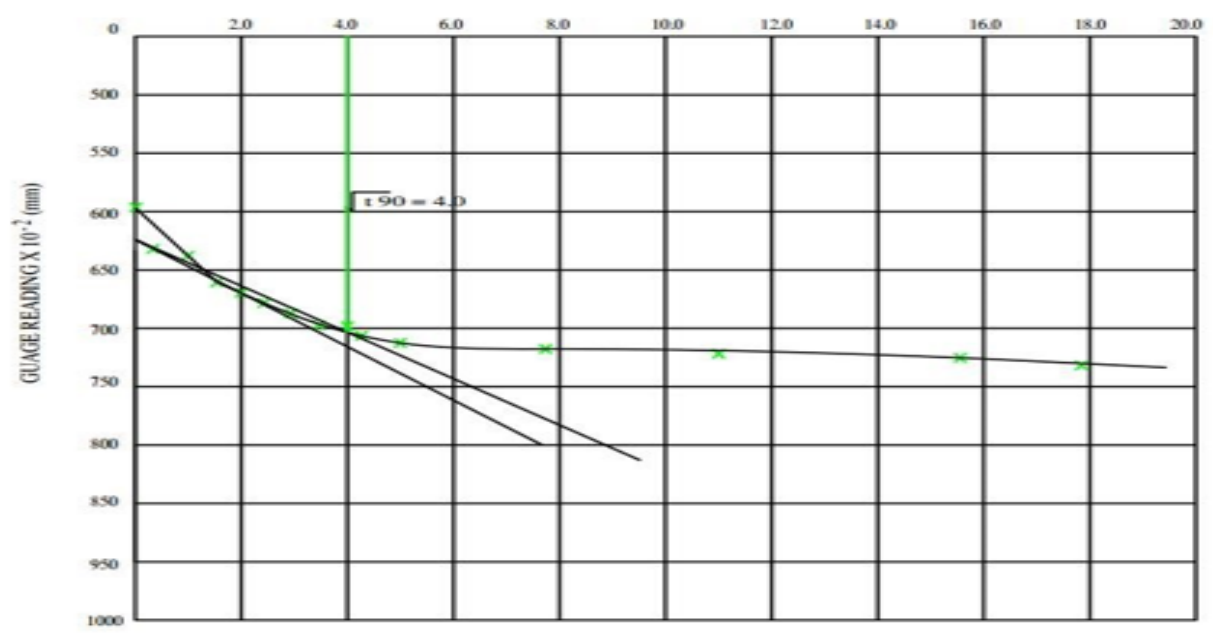

Figure 7. Typical consolidation curve in the area (TP2)

\subsection{Shear Strength (Consolidated Undrained Triaxial Test)}

The triaxial test is performed to determine the shear strength and stiffness of soil for use in geotechnical design. Primary parameters obtained from the test may include the angle of shearing resistance $\varphi$, cohesion $c^{\prime}$. The consolidated undrained (CU) test procedure was used as it allows shear strength and strength parameters to be determined based on the effective stresses (i.e. $\varphi$ and $c^{\prime}$ ) with a fast rate of shearing. Back pressure was carefully applied and increased with time. A cylindrical specimen with a diameter of $50 \mathrm{~mm}$ and height of $100 \mathrm{~mm}$ was molded and used. The test was performed on three individual samples with normal pressures of 100, 200 and
$300 \mathrm{kN} / \mathrm{m}^{2}$. The result is presented as Table 7 . Cohesion (C) range from $12 \mathrm{kN} / \mathrm{m}^{2}$ (TP2) to $16 \mathrm{kN} / \mathrm{m}^{2}$ (TP1), angle of internal friction $\left(^{\circ}\right)$ range from $28^{\circ}$ (TP2) to $31^{\circ}$ (TP1) while the shear strength range from $258.81 \mathrm{kN} / \mathrm{m}^{2}$ (TP3) to $338 \mathrm{kN} / \mathrm{m}^{2}$ (TP4).

Table 7. Shear strength parameter of samples

\begin{tabular}{|c|c|c|c|}
\hline $\begin{array}{c}\text { Sample } \\
\text { ID }\end{array}$ & $\mathrm{C}\left(\mathrm{KN} / \mathrm{m}^{2}\right)$ & $\phi^{(0)}$ & $\mathrm{T}\left(\mathrm{KN} / \mathrm{m}^{2}\right)$ \\
\hline OG1 & 16 & 30 & 337.13 \\
\hline OG2 & 12 & 28 & 270.76 \\
\hline OG3 & 14 & 26 & 258.81 \\
\hline EF1 & 10 & 31 & 338.00 \\
\hline IP1 & 15 & 28 & 336.20 \\
\hline
\end{tabular}


This result follows the water content, grain-size distribution and specific gravity of the soils. Figure 8 represents the Mohr circle plot for TP1. Localized failure mode was observed. This was indicated by development of deformation bands and sudden reduction in the average strength. Generally, this typifies the Mohr circle plot and failure mode of soils in the area. The sample which the figure represents is moist and relatively cohesive with good proportion of fines mixed with the sands. Grains of sand recovered from this point are largely angular to sub-angular.

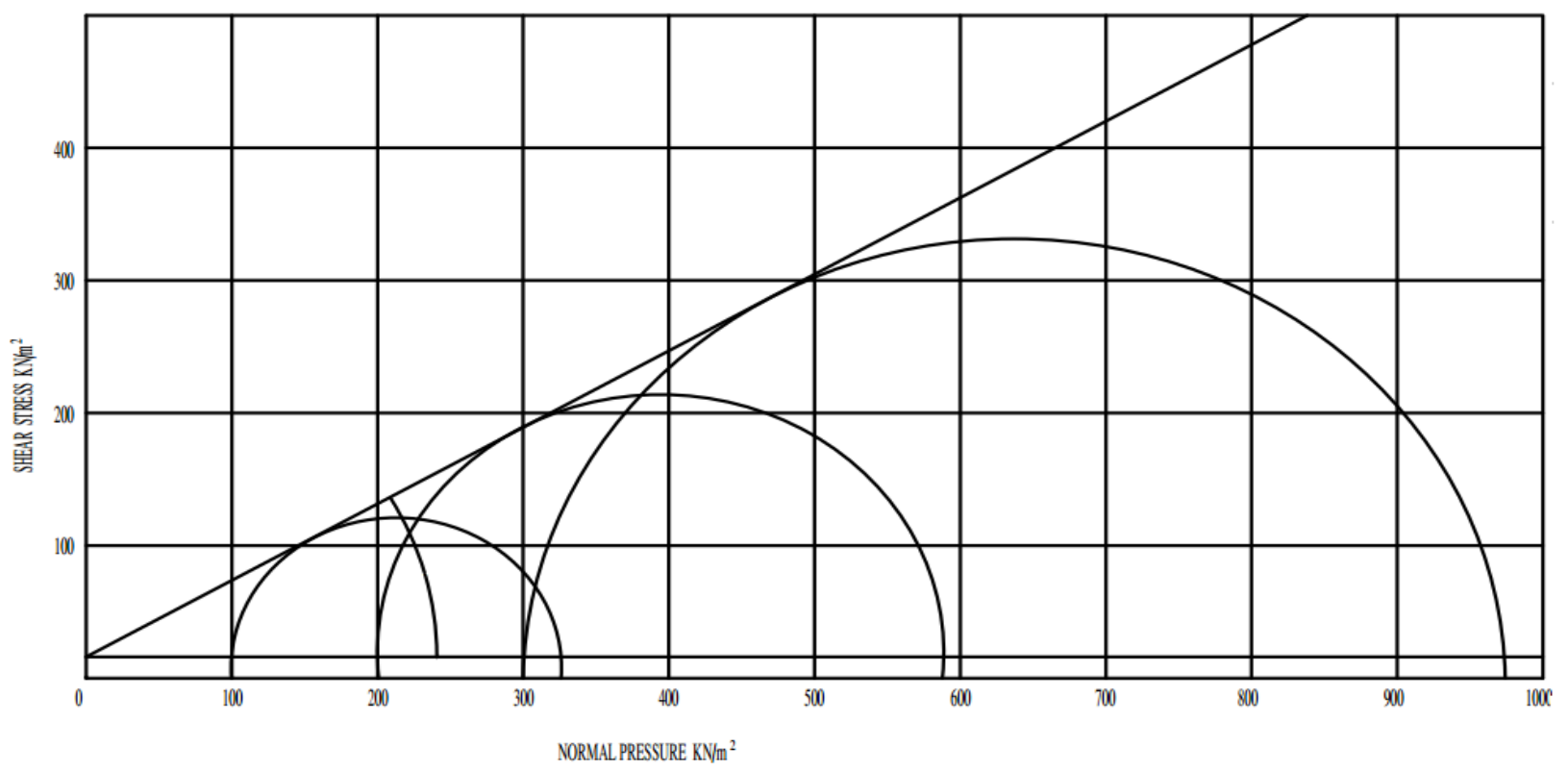

Figure 8. A typical Mohr circle plot of a sample (TP1)

The shear strength measured in the soils is largely attributable to the inter-particle frictional force of sand particles with very minimal component of the shear strength due to particles cohesion.

Spatially, soils in the area show broadly similar physical properties. Northernmost TP1 and Southernmost TP5 showed similar physical properties. They appear moist and relatively cohesive with good proportion of fines mixed with the sands. Grains are largely angular to sub-angular. Soils around TP2 and TP3 showed similar physical properties. They appear moist and soft, less cohesive with very low proportion of fines among the sand. Texturally, the sands are largely equigranular and rounded. It has a gritty feel. Soils around TP4 feels gritty and moist. It is non-cohesive and appears poorly graded. The grains appear almost equigranular. Geotechnically, Permeability range from $3.36 \times 10^{-4} \mathrm{~m} / \mathrm{sec}-7.8 \times 10^{-6} \mathrm{~m} / \mathrm{sec}$. $\mathrm{Mv}$ under $250 \mathrm{kN}$ range from $1.3 \times 10^{-4} \mathrm{~m}^{2} / \mathrm{kN}-7.27 \times 10^{-}$ ${ }^{5} \mathrm{~m}^{2} / \mathrm{kN}$ while $\mathrm{Cv}$ at a stress level of $250 \mathrm{kN}$ is not more than $2.43 \mathrm{~m}^{2} /$ year and would not be less than $1.33 \mathrm{~m}^{2} /$ year. The plastic limit range from $11-17 \%$ with average specific gravity of $2.64 \mathrm{~g} / \mathrm{cm}^{3}$. MDD is highest at $1.85 \mathrm{~g} / \mathrm{cm}^{3}$ at an OMC of $12.11 \%$ and is lowest at $1.67 \mathrm{~g} / \mathrm{cm}^{3}$ at an OMC of $11.99 \%$. UCS range from $31-45 \mathrm{kN} / \mathrm{m}^{2}$ while shear strength is between $258.81 \mathrm{kN} / \mathrm{m}^{2}$ to $338 \mathrm{kN} / \mathrm{m}^{2}$. Comparative analysis of the result of index and engineering properties tested, show that soils from the southern part of the studied area appear to be more stable and suitable for engineering structures compared the soils obtained from the northern part of the studied area.

\subsection{Comparism of the Geotechnical Properties of Soil with the Nigerian Standard to Determine Suitability for Different Type of Structures}

\section{A) As General fill and embankment materials}

From Table 8 above, it can be seen that all the soil in the study area meet the requirements of all the tested properties for use as fill and embankment materials as stipulated by the Nigerian federal ministry of works and housing [11]. Soils from this area can be used for this purpose. An embankment or fill material should be capable of providing strength-support needed to carry the overlying load as well as permit safe drainage of fluid. It should be well graded, have low compressibility with high shear strength and bearing capacity with high density.

Table 8. Table of Nigerian specification for fill \& embankment Vs measured soil properties

\begin{tabular}{|c|c|c|c|c|c|c|c|c|c|}
\hline \multirow{2}{*}{ S/No } & \multirow{2}{*}{ Property } & \multirow{2}{*}{ Nigerian Standard required } & \multicolumn{3}{|c|}{ Sample point soil property } & \multirow{2}{*}{ Average } & \multirow{2}{*}{ Remark } \\
\cline { 4 - 8 } & & & TP1 & TP2 & TP3 & TP4 & TP5 & & \\
\hline 1 & MDD $\left(\mathrm{g} / \mathrm{cm}^{3}\right)$ & $>0.04$ & 1.70 & 1.73 & 1.67 & 1.67 & 1.85 & 1.72 & Good \\
\hline 2 & OMC (\%) & $<18$ & 12.05 & 12.01 & 11.99 & 12.12 & 12.11 & 12.06 & Good \\
\hline 3 & LL (\%) & $<40$ & 28 & 28 & 27 & 28 & 35 & 29.20 & Good \\
\hline 4 & PL (\%) & $<20$ & 17 & 16 & 10 & NP & 18 & 15.25 & Good \\
\hline 5 & $\%$ passing No. 200 sieve & $\leq 35$ & 18.3 & 12.0 & 11.0 & 16.6 & 13.9 & 14.36 & Good \\
\hline & & \multicolumn{7}{|c|}{ General Comment: } & \multicolumn{3}{c|}{ Excellent Material } \\
\hline
\end{tabular}


Table 9. Table of Nigerian specification for Sub-base material Vs measured soil properties

\begin{tabular}{|c|c|c|c|c|c|c|c|c|c|}
\hline \multirow{2}{*}{ S/No } & \multirow{2}{*}{ Property } & \multirow{2}{*}{ Nigerian Standard required } & \multicolumn{4}{|c|}{ Sample point soil property } & \multirow{2}{*}{ Average } & \multirow{2}{*}{ Remark } \\
\cline { 4 - 7 } & & & TP1 & TP2 & TP3 & TP4 & TP5 & & \\
\hline 1 & LL (\%) & $<35$ & 28 & 28 & 27 & 28 & 35 & 29.20 & Good \\
\hline 2 & PL (\%) & $<16$ & 17 & 16 & 10 & NP & 18 & 15.25 & Good \\
\hline & & & \multicolumn{5}{|c|}{ General Comment: } & \multicolumn{4}{c|}{ Good Material } \\
\hline
\end{tabular}

Table 10. Table of Nigerian specification Base course material Vs measured soil properties

\begin{tabular}{|c|c|c|c|c|c|c|c|c|c|}
\hline \multirow{2}{*}{ S/No } & \multirow{2}{*}{ Property } & \multirow{2}{*}{ Nigerian Standard required } & \multicolumn{3}{|c|}{ Sample point soil property } & \multirow{2}{*}{ Average } & \multirow{2}{*}{ Remark } \\
\cline { 4 - 8 } & & & TP1 & TP2 & TP3 & TP4 & TP5 & & \\
\hline 1 & LL (\%) & $\leq 30$ & 28 & 28 & 27 & 28 & 35 & 29.20 & Good \\
\hline 2 & PL (\%) & $\leq 13$ & 17 & 16 & 10 & NP & 18 & 15.25 & Not Good \\
\hline 3 & UCS (KPa) & $>103$ & 37 & 40 & 36 & 31 & 45 & 37.80 & Not Good \\
\hline 4 & \% passing No. 200 sieve & $5-15$ & 18.3 & 12.0 & 11.0 & 16.6 & 13.9 & 14.36 & Good \\
\hline & & \multicolumn{6}{|c|}{ General Comment } & \multicolumn{3}{c|}{ Not suitable } \\
\hline
\end{tabular}

\section{B) As Sub-base materials}

From Table 9 above, it can be seen that the soils in the area meet the requirements of all the tested properties for use as sub-base material as stipulated by [11]. Materials can be sourced from the studied area and used as sub-base material for pavement construction.

Its role is to distribute the load evenly over the subgrade and allow for enough drainage and as a result the material should be capable of meeting the strength requirement for this load distribution and drainage function.

\section{C) As Base course material}

From Table 10, it can be seen that the soil meets the liquid limits and gradation requirements for use as base material by [11] but do not meet the stipulated requirement for plastic limit and unconfined compressive strength (UCS). The base course serves to provide the stable foundation needed to support either additional layers of aggregates or the placement of an asphalt concrete wearing course which is applied directly on top of the base course. It should be made of a mix of different sizes and quality of aggregate ranging from coarse to fine. As base course lies close under the pavement surface it is subjected to severe loading, thus the material in a base must be of high compressive strength and must be of extremely high quality and its construction must be done carefully. The requirements of a satisfactory soil aggregate surface are stability, resistance to abrasion and resistance to penetration of water.

\section{Conclusion}

Geotechnically, the area was observed to be dominated by sand with proportionate amount of fines (silty and clayey sand) with the activity of the fine ranging from inactive to normal. The area showed variation in permeability and consolidation under load depending on the amount of fines, gradation, specific gravity and moisture content with relatively low shear strength which is largely attributable to the inter-particle friction between the sands. There is need for compaction of soils if maximum densification is to be achieved as the ZAV curves show that the soils are naturally far from attaining maximum density or zero-air void status. The soils could be compacted in place to maximum dry density at other water content level with greater compactive effort at the dry side of the compaction curve to attain better engineering properties. The geotechnical implication of the above properties range from susceptibility to marginal volume change (swelling and shrinkage) when not compacted, differential settlement to low shearing resistance.

A comparism with the specifications of the NFMWH 2003, shows that materials from the area would serve as excellent fill and embankment material. It also met the specification for use as Sub-base material and would serve as good material for that purpose but do not meet the requisite properties to qualify it for usage as base material in pavement construction. Hence, these materials are quality reserves for fill, embankment and sub-base construction but not for bases.

\section{Acknowledgements}

The authors reserve appreciation to Abubakar Tafawa Balewa University, Bauchi for the time allowed to conduct this research.

\section{References}

[1] Habeeb, A.O., Olabambo, A.A., and Oladipupo, S.O. 2012. Investigation of the geotechnical engineering properties of laterite as subgrade and base materials for road construction in Nigeria. Civil and Environmental Research, 2 (8). 23-41.

[2] Salter, R.J. 1988. Highway design and construction. Macmillan Education, UK, 159-192.

[3] Agbede, O.A. 1992.Characteristics of tropical red soils as foundation materials. Nigerian journal of Science, 26. 237-242.

[4] Sherwood, P.T. and Pike, D.C. 1984. Errors arising in the measurement of the grading of sub-base aggregates. Bulletin of International Association of Engineering Geology. 29 (1). 437-441.

[5] Nzabakurikiza, A., Onana, V.L., Ze, A.N., et al. 2016. Geological, geotechnical and mechanical characterization of lateritic gravels from eastern Cameroon for road construction purposes. Bulletin of Engineering Geology and Environment.

[6] Akpokodje, E.G. 1986. The geotechnical properties of lateritic and non-lateritic soils of south-eastern Nigeria and their evaluation for road construction. Bulletin of International Association of Engineering Geology.

[7] Okogbue, C.O and Aghamelu, O.P 2016. Comparism of the geotechnical properties of crushed shales from southeast Nigeria. Bulletin of Engineering Geology and Environment. 
[8] Martins, O.I., Calistuis, A., \& Sambaba, O. 2012. Erodibility of soils of the southwest of Benue State, Nigeria. The pacific Journal of Science and Technology, 13 (2). 437-447.

[9] Nwajide, C.S. 2013. Geology of Nigerian sedimentary Basins. CSS Bookshop, Awka, 277-340.

[10] Amajor, L. C. 1984. Sedimentary facies analysis of the Ajali Sandstone (Upper Cretaceous), southern Benue Trough. Journal of Mining and Geology, 21, 171-176.

[11] NFMWH (1972, Revised: 1974, 2003).General specifications for Roads and Bridges, Vol. II, Fed. Highway department, FMWH, Lagos, Nigeria.

[12] Arora K.R. 2004. Soil mechanics and foundation Engineering. Standard publishers Distributors, Delhi, 69-257.

[13] Krynine, D.P., and Williams, R.J. 2005. Principles of Engineering Geology and Geotechnics.CBS publishers, Cochin, India, 730p.

[14] Ameh, D.P., Ogbonnaya, I. \& Bernadette, U. 2016. Evaluation of the bearing capacity of near surface soils using intergrated method: A case study of Otukpa in Ogbadibo L.G.A of Benue State, Northcentral Nigeria. Journal of Geological Society of India. V.90, pp.93-101
[15] Zolfaghari, Z., Mosaddeghi, M.R., Ayoubi, S. et al. (2015). Soil Atterberg limits and consistency indices as influenced by land use and slope position in Western Iran. Journal of Mountain Science. 12 (6). 1471-1483.

[16] Skempton AW (1953). The colloidal activity of clays. In: Proceedings of the third international conference on soil mechanics and foundation engineering. Zurich, Switzerland, ICOSOMEF, pp 57-61.

[17] Braja, M. Das. 2002. Soil mechanics laboratory manual. $6^{\text {th }}$ Edition. Oxford University Press.

[18] Babic, B., Prager, A. \& Tatjana, R. 2000. Effect of fine particles on some characteristics of granular base course. Materials and Structures, 33 (7). 419-424.

[19] Belkhatir, M., Schanz, T. \& Arabi, A. 2013. Effect of fines content and void ratio on the saturated hydraulic conductivity. and undrained shear strength of sand-silt mixtures. Environmental Earth Science, 70 (6). 2469-2479.

[20] Osinubi, K.J., Eberemu, A.O., Bello, A.O. \& Adzegah, A. 2012. Nigerian journal of Technology. 31 (3) 277-287. 